\title{
Ames Testi Kullanılarak Dentis Pestisitinin Mutajenitesinin Belirlenmesi
}

\author{
Dilek AKYIL ${ }^{1}$
}

ÖZET: Bu çalışmada, tarım sektöründe oldukça yaygın olarak kullanılan Dentis pestisitinin mutajenik etkisi, kısa zamanlı bakteriyel mutajenite test sistemlerinden biri olan Salmonella/mikrozom test sistemi ile araştırılmıştır. Çalışmada Salmonella typhimurium'un iki suşu olan TA98 ve TA100 suşları kullanılmıştır. Bunun için her iki suş mikrozomal enzimler içeren metabolik aktivasyon (S9) varlığında ve yokluğunda, Dentis'in 250, 25, 2.5, 0.25, $0.025 \mu \mathrm{g} /$ plak konsantrasyonlarında iki bağımsız paralel deneyde test edilmiştir. Her test suşu için pozitif kontroller de kullanılmıştır. Elde edilen veriler Dunnett-t testi ile istatistiksel olarak değerlendirilmiştir. Sonuç olarak; Dentis pestisiti TA98 ve TA100 suşlarının her ikisinde de S9 varlığında ve yokluğunda $250 \mu \mathrm{g} / \mathrm{plak}$ konsantrasyonunda mutajenik aktivite göstermiştir.

Anahtar Kelimeler Ames testi, dentis, mutajenite, piretroid

\section{Evaluation of Dentis Pesticide Mutagenicity with Ames Test}

\begin{abstract}
In this study, the mutagenic effect of Dentis used in agriculture widely have been investigated by using short-term bacterial mutagenicity test system namely Salmonella/microsome. In the Salmonella/microsome test system the mutant strains used are Salmonella typhimurium TA98 and TA100. Therefore, both test strains were tested in the absence or presence of S9 metabolic activation. For this, 250, 25, 2.5, 0.25, 0.025mg/plate concentrations of Dentis were tested in two paralel independent experiments. The positive controls also were used in each tester strains. The obtained data were statistically evaluated by Dunnett's t-test. Consequently; Dentis has found mutagenic both TA98 and TA100 strains with or without S9 only 250mg/plate concentration.
\end{abstract}

Keywords: Ames test, dentis, mutagenicity, piretroid

Dilek AKYIL (0000-0002-7048-3808), Afyon Kocatepe Üniversitesi, Fen-Edebiyat Fakültesi, Moleküler Biyoloji ve Genetik Sorumlu yazar/Corresponding Author: Dilek AKYIL, dilekakyil9@gmail.com 


\section{GİRIŞ}

Teknolojideki hızlı gelişim ve batılı yaşam tarzının benimsenmesi ile birlikte kimyasalların insan hayatında daha fazla yer alması ve her alanda çok yaygın olarak kullanılması sonucu bu maddelerin insan sağlığ 1 ve doğal kaynaklar üzerinde olumsuz etkilerinin olduğu bilinmektedir (Kim et al., 2010). Endüstrinin gelişmesiyle birlikte mesleki olarak kimyasal maddelere maruziyet durumu da artmış olup kullanılan bu kimyasal maddeler için tehlike değerlendirilmesi gerekliliği de artmıştır (Alzuet et al., 1996; Oğuz, 2011). Mesleki olarak en sık maruz kalınan kimyasal maddelerden biri de pestisitlerdir. $\mathrm{Bu}$ maddeler tarımda verimi artırmak için sıklıkla kullanılan kimyasal maddeler arasındadır ve pestisitler içerisinde en yaygın kullanılan gruplardan biri de pretriodlerdir. Piretroidler, dünyada 30 y1lı aşkın bir süredir tarımda, küçükbaş hayvanlarda ektoparazitlere karşı yaygın olarak kullanılan insektisitlerdir. Düşük memeli toksisiteleri nedeniyle piretroid bileşiklerin kullanımı son zamanlarda artış göstermiştir ve 1990'ların ortalarında dünya insektisit piyasasının \%23'ünü piretroid maddeler oluşturmuştur (Soderlund et al., 2002; Piner, 2009).

Günlük yaşantımızda sıklıkla doğal ya da kimyasal maddelerle yüz yüze geldiğimiz için araştırmacılar, kimyasal maddelerin mutajenik/ karsinojenik risklerini belirlemek için in vivo test sistemleri yerine daha hızlı ve güvenilir sonuç alınan in vitro test sistemlerini tercih etmektedirler. $\mathrm{Bu}$ testler kimyasal maddelerin mutajenik etkilerinin belirlenmesi amacı ile kullanılmakta olup bu metodlar arasında en yaygın olarak kullanılanları kısa zamanda sonuçlanan bakteriyel testlerdir (Fuse et al., 2011; Oğuz, 2011). Ames (Salmonella/ Mikrozomal) testi, geçmişten günümüze kadar yaygın kullanım alanı bulan bakteriyel bir test sistemi olup, araştırmacılar tarafından farklı kimyasal maddelerin mutajenik aktivitelerinin değerlendirilmesinde sıklıkla kullanılmıştır (Healy et al., 2003; Coral et al., 2009; Aky1l, 2013; Eren, 2016). Bu çalışmada piretroid grubu bir pestisit olan Dentis'in ticari formunun kisa zamanlı bir bakteriyel test sistemi olan Ames testi ile mutajenik aktivitesinin değerlendirilmesi amaçlanmıştır.

\section{MATERYAL VE METOD}

\section{Materyal}

Deneyde, Salmonella typhimurium LT2 atasal suşundan in vitro mutasyonlarla geliştirilmiş TA98 ve TA100 suşları kullanılmıştır (Maron and Ames, 1983). TA 98 suşu çerçeve kaymasına yol açan mutajenlerin, TA 100 suşu ise baz çifti değişimine yol açan mutajenlerin belirlenmesi için kullanılmıştır. Çalışmada piretroid grubuna ait olan bir insektisit olan Dentis kullanılmış ve ticari formu Koruma Klor Alkali Sanayi ve Ticaret Anonim Şirketi (Kocaeli)'nden temin edilmiştir. S9'lu deneyin gerçekleştirilebilmesi için gerekli olan S9 fraksiyonu ticari olarak hazır bir şekilde temin edilmiştir (Sigma-Aldrich -S2067).

Dentis pestisitinin deneyde kullanilan test konsantrasyonları steril distile su ile deney sirasında taze olarak hazırlandı ve çalışmada bu maddeye ait beş farklı konsantrasyon kullanıldı. Sitotoksik dozun belirlenebilmesi için bir ön çalışma yapıldı ve bu ön çalışma sonunda elde edilen konsantrasyonlar çalışmada kullanıldı. Bu konsantrasyonlar Dean et al., (1985) yöntemine uygun olarak belirlendi ve sitotoksik olmayan dozlarla çalışıldı. Test suşlarının genetik işaretlerinin doğrulanması çalışmada kullanılan S. typhimurium TA98 ve TA100 suşlarının genetik işaretlerinin kontrolü, mikrozomal fraksiyonun hazırlanması ve Ames testi Maron ve Ames'in yöntemine uygun yapıldı. Deneyler S9 fraksiyonu varlığında ve yokluğunda olmak üzere iki grup halinde çalışıldı. Her doz paralel 3 plak halinde denendi ve farklı zamanlarda iki bağımsız deney yapıldı. Ayrıca deneyde pozitif ve negatif kontrollerde kullanıldı. Pozitif kontrol olarak TA98 suşu S9'lu deney için 2-aminofluorene, S9'suz deney için 4-nitro-o-phenylenediamine kullanilırken, TA100 suşu için S9'lu deneyde 2-aminoanthracene, S9'suz deney için ise sodyum azide kullanıldı.

\section{Bakterilerin genotiplerinin kontrol edilmesi}

Testin güvenilirliği açısından test suşlarının orijinal mutasyonlara sahip olup olmadıkları Histidin gereksinimi, Rfa mutasyonu, UvrB mutasyonu, R faktörü testlerle kontrol edildi.

Histidin gereksinimi kontrolü için nütrient brothda (NB) bir gece üretilen bakterilerden sabah minimal glukoz agar ve histidin/biyotin (HB) plaklarına çizgi ekim yapıld1. $37^{\circ} \mathrm{C}$ 'de $48-72$ saat inkübasyondan sonra HB plaklarında üreme gözlenirken minimal glukoz 
agar (MGA) plaklarında üreme gözlenmedi. $u v r \mathrm{~B}$ mutasyonu kontrolü için NB'da bir gece büyütülen bakteri kültüründen 1 öze dolusu alınıp nutrient agar (NA) plağının tamamına paralel ekim yapıldı. Plakın yarısı plastik bir plaka ile kapatılıp 15 watt gücünde bir UV lambası ile $33 \mathrm{~cm}$. yüksekten $8 \mathrm{sn}$. süre ile 1şınlandı. Işınlanmadan sonra petri kapakları kapatılıp $37{ }^{\circ} \mathrm{C}$ 'de 24 saat inkübe edildi. Bu sürecin sonunda UV'ye maruz kalan kısımda üreme olmazken, plastik kapakla kapatılan kısımda normal bir üreme gözlendi. Rfa mutasyonu kontrolü için NB'da bir gece büyütülen bakteri kültüründen $0.1 \mathrm{ml}$ sıvı kültür alınarak, $45^{\circ} \mathrm{C}$ su banyosunda tutulan $2 \mathrm{ml}$ top agar üzerine ilave edilip daha sonra NA plaklarına dökülerek plaklara 8 işareti yapıldı. $10 \mathrm{dk}$. donması beklendikten sonra plağın ortasına $0.5 \mathrm{~cm}$ çaplı steril filtre kağıdı diski yerleştirilip diskin ortasına \%0.1'lik kristal viyole karışımından 10 $\mu 1$ damlatıld1. Sonra plaklar $37^{\circ} C^{\prime}$ de 24 saat inkübe edildi. İnkübasyon sonunda disk çevresinde $14 \mathrm{~mm}$ 'lik üreme olmayan zon gözlendi. R-faktör varlığ kontrolü için, NB içinde bakteri kültürü (\%0.8 Ampisilin/0.02 $\mathrm{M} \mathrm{NaOH}$ ) ampisilin içeren histidin/biyotin/ampisilin (HBA) plaklarına çizgi ekim yapılarak, $37{ }^{\circ} \mathrm{C}$ 'de 24 saat inkübasyonu sonunda, plazmid içeren mutant bakterilerin ampisilinli ortamda büyüdükleri gözlendi.

\section{Test maddelerinin sitotoksik etkilerinin saptanması}

Sitotoksik dozların belirlenebilmesi için $45{ }^{\circ} \mathrm{C}^{\prime}$ lik su banyosunda bekletilen 2 ml'lik top agar içeren deney tüpleri içerisine $100 \mu \mathrm{l}$ bakteri ve $100 \mu \mathrm{l}$ steril distile su içerisinde çözülmüş test bileşiklerinin değişik konsantrasyonlarından ilave edilerek nütrient agar plaklarına ekimi gerçekleştirildi. Deneye paralel olarak pozitif kontrol plaklarının ekimi de yapıldı. Plaklar $37{ }^{\circ} \mathrm{C}$ 'de 24 saat inkübe edildi, inkübasyondan sonra plaklardaki ortalama koloni sayısı belirlendi ve kontrol plakları ile karşılaştırılarak toksik ve toksik olmayan dozlar belirlendi. Deney sonunda sitotoksik doz 250 $\mathrm{mg} / \mathrm{plak}$ olarak belirlendi ve çalışmada bu dozun altındaki 5 farklı konsantrasyon kullanıldı.

\section{Ames mutajenite testinin yapılışı}

S9'suz deneyde $45^{\circ} \mathrm{C}$ 'lik su banyosunda bekletilen $2 \mathrm{ml}$ 'lik top agar içeren deney tüpleri içerisine $100 \mu 1$ bakteri ve $100 \mu 1$ test maddesi kültürü eklenmiştir. Tüpler vortekslenerek minimal glukoz agar plaklarına dökülmüş, plaklar 8 çizilerek homojen olarak top agarın plak üzerine dağılması sağlanmıştır. S9 fraksiyonu varlığında yapılan deneylerde ise bu karışım içerisine
$500 \mu \mathrm{l}$ S9 karışımı ilave edilmiş deney sonunda top agarlar petri yüzeyinde donduktan sonra $37^{\circ} \mathrm{C}$ ' de 48 72 saat inkübasyona bırakılmıştır. İnkübasyon süresi sonunda petrilerdeki koloniler sayılmıştır. Deneyde her bir doz için 3 ayrı plak çalışılmış ve birbirinden bağımsız iki deney yapılmıştır. Sonuçların değerlendirilebilmesi için deneylerde spontan kontrol ve pozitif kontrol grubu da kullanılmıştır.

\section{Verilerin istatistiksel analizleri}

Ames testinde Dentis'in mutajenik aktivitesi Salmonella typhimurium'un TA98 ve TA100 mutant suşları ile araştırılmış ve istatistiksel analiz aşamasında sonuçların değerlendirilmesi SPSS 18.0 for Windows paket programında Dunnet-t testi (2 yönlü) kullanılarak yapılmıştır ve verilerin ortalamaları arasındaki $\mathrm{p}<0.05$ düzeyindeki farkl1l1klar göz önünde bulundurularak belirlenmiştir.

\section{BULGULAR VE TARTIŞMA}

Pestisitlerin fazla miktarlarda ve sık kullanımı tarımsal ürün kayıplarını azaltırken, bir yandan da insanlar için giderek artan bir sağlık riski oluşturmaktadır. Pestisitler ve bunların kalıntıları zamanla biyolojik besin zincirine katılarak çevreyi ve içinde yaşayan tüm canlıları doğrudan ya da dolaylı olarak etkilemektedir.

Piretroidlerin geniş bir kullanım alanına sahip olmaları, memelilerde zehirlilik derecelerinin ihmal edilebilir düzeyde düşük olması ve doğal koşullarda kısa sürede parçalanmaları en önemli avantajlarıdır (Çolak, 2009). Ancak bu kimyasalların günümüzde yaygın bir şekilde kullanılması canlılarda mutajenik etki gösterip göstermediği sorusunu akla getirmiştir. Konuyla ilgili olarak farklı deney sistemleri ile yapılan çalışmalar pestisitlerin hücrelerde çeşitli bozukluklara yol açtığını göstermiştir. Yaygın olarak kullanılan pestisitlerin hedef olmayan canlı organizmalar üzerinde istenmeyen etkilere neden olduğu bilinmektedir ve bu olumsuz etkileri üzerine pek çok çalışma yapılmaktadır.

$\mathrm{Bu}$ çalışmada Dentis pestisitine Ames testi uygulanmış olup deneyde Salmonella typhimurium LT2 atasal suşundan in vitro mutasyonlar ile elde edilmiş S. typhimurium TA98 ve TA100 mutant suşları kullanılmıştır. Çalışmaya ait S9 fraksiyonu varlığında ve yokluğunda plak inkorporasyon testi sonuçları Çizelge 1'de verilmiştir. 
Çizelge 1. Salmonella typhimurium TA98 ve TA100 suşları ile Dentis pestisitinin S9 fraksiyonu varlığında ve yokluğunda plak inkorporasyon testi sonuçları

\begin{tabular}{|c|c|c|c|c|c|}
\hline \multirow{3}{*}{ Madde } & \multirow{3}{*}{$\begin{array}{c}\text { Doz } \\
(\mu \mathrm{g} / \text { plak })\end{array}$} & \multicolumn{4}{|c|}{$\begin{array}{c}\text { Revertant Sayısı } \\
\text { Aritmetik Ortalama } \pm \text { Standart Sapma }\end{array}$} \\
\hline & & \multicolumn{2}{|c|}{ TA98 } & \multicolumn{2}{|c|}{ TA100 } \\
\hline & & - S9 & $+\mathrm{S9}$ & - S9 & $+\mathrm{S9}$ \\
\hline \multirow{5}{*}{ Dentis } & 250 & $59.86 \pm 7.6^{*}$ & $110.78 \pm 4.62 *$ & $221.01 \pm 4.26^{*}$ & $389.20 \pm 13.61 *$ \\
\hline & 25 & $50.25 \pm 1.5$ & $99.23 \pm 4.24$ & $194.40 \pm 2.48$ & $357.21 \pm 12.48$ \\
\hline & 2.5 & $48.77 \pm 3.12$ & $102.82 \pm 1.12$ & $175.00 \pm 7.74$ & $364.12 \pm 9.75$ \\
\hline & 0.25 & $37.88 \pm 3.98$ & $89.14 \pm 2.23$ & $118.4 \pm 3.85$ & $302.14 \pm 8.14$ \\
\hline & 0.025 & $35.42 \pm 3.75$ & $79.15 \pm 3.64$ & $97.42 \pm 3.73$ & $245.45 \pm 7.45$ \\
\hline NK & 100 & $27.12 \pm 4.11$ & $47.20 \pm 6.27$ & $94.21 \pm 7.12$ & $164.17 \pm 6.25$ \\
\hline SA & 10 & & & $2772.10 \pm 45.15^{*}$ & \\
\hline $2 \mathrm{AA}$ & 5 & & & & $2228.01 \pm 45.24 *$ \\
\hline $2 \mathrm{AF}$ & 200 & & $1012.14 \pm 14.05 *$ & & \\
\hline NPD & 200 & $1290.32 \pm 22.75^{*}$ & & & \\
\hline
\end{tabular}

*Kontrole göre revertant sayısı p<0,05 düzeyinde anlamlı (Dunnett-t test) NK: Negatif Kontrol, SA: Sodyum azid, 2AA: 2-aminoanthracene, 2AF: 2-aminofluorene, NPD: 4-nitro-o-fenilendiamine. *:mutajen

Salmonella suşları, histidin operonundaki çeşitli genlerde farklı mutasyonlara sahiptir; bu mutasyonların her biri farklı mekanizmalar ile etki gösteren mutajenlere karşı cevap oluşturmak için dizayn edilmiştir (Ames and Maron, 1983; Healy et al., 2003). Bu mutant suşlar histidin üretemeyen özel suşlardır. Çalışma sonunda histidin üretebilir hale gelen bakterilerin koloni sayımlarının gerçekleştirilmesi ile mutajeniteden bahsedilmektedir. Değerlendirmeye göre Ames testinde negatif kontrol grubunun koloni sayısını iki katına çıkaran konsantrasyon değeri mutajenik konsantrasyon olarak kabul edilmektedir. Koloni sayısında doza bağlı bir artış olma durumunda ise bu maddenin, zayıf mutajenik etkiye sahip olduğu kabul edilmektedir (Mortelmans and Zeiger, 2000).

$\mathrm{Bu}$ çalışmada deney öncesinde tüm suşlar için spontan geri dönüşüm sayısı bulunarak test bakterilerinin deneyler için uygunluğu doğrulanmıştır. Bununla beraber mutant olan bu bakteriler, genetik özelliklerini çok çabuk değiştirebildikleri için her deneyden önce mutlaka genetik kontrolleri yapılarak deney için uygun olup olmadıklarının sağlaması yapılmıştır. Genetik kontrollerin yanı sıra kullandığımız pestisitlerin uygulanacak dozlarını belirlemek için denemeler kurulmuş ve her pestisit için sitotoksik dozlar belirlenmiştir. Deney sonunda elde edilen sonuçlar, standart sapmaları ile birlikte ortalamaları alınarak, istatistiksel açıdan Dunnett-t testi (2 yönlü) kullanılarak, negatif kontrol ile karşılaştırılıp değerlendirilmiştir.

Dentis pestisiti piretroid ester grubuna giren ve tarımda yaygın olarak kullanılan bir insektisit olup yaptığımız çalışmada TA98 ve TA100 suşlarının S9 fraksiyonu varlığında ve yokluğundaki uygulamalarda, kullanılan konsantrasyonlar arasinda $250 \mu \mathrm{g} /$ plak dozlarında her iki suşta da koloni sayıları kontrol grubunun iki katını aşmıştır. $\mathrm{Bu}$ sebeple kullanılan konsantrasyonlardan sadece bu dozda mutajenik aktiviteye rastlanmıştır. Bu çalışma dışında pek çok farklı piretroid grubu pestisitler de farklı araştırıcılar tarafından çeşitli test sistemlerinde değerlendirilmeye alınmıştır (Villarini et al., 1998; Romero et al., 2012; Song et al., 2015; Verma et al., 2016).

Mutajenitenin belirlenmesi için yaygın olarak kullanılan test sistemlerinden biri de Ames testidir. Pluijmen ve arkadaşları 1984 yılında piretroid grubuna dahil olan altı farklı pestisiti (Biyoresmetrin, Deltametrin, Permetrin, Sipermetrin, Sismetrin ve Fenvalerat) Ames testi ile TA98 ve TA100 suşları üzerinde S9 varlığında ve yokluğunda değerlendirmiş ve çalışma sonunda herhangi bir mutajenik aktiviteye 
rastlamamışlardır. Yine Herrera ve Laborda (1988) yaptıkları bir çalışmada piretroid grubuna ait Aletrin, Fenvalerat, Resmetrin ve Permetrin pestisitlerini Ames testi ile Salmonella tyhimurium'un TA97, TA98, TA100, TA104, TA1535, TA1537 ve TA1538 suşları üzerinde mutajenitesini araştırmışlar ve sonuç olarak Resmetrin, Permetrin ve Fenvalerat'ın S9 fraksiyonu varlığında ve yokluğunda mutajen olmadığını belirlemişlerdir. Aletrin ise TA97, TA100 ve TA104 suşları üzerinde S9 varlığında mutajenik olarak bulunmuştur.

Yaptığımız çalışmada Dentis pestisitinin ticari formunun farklı dozları değerlendirilmeye çalışılmış ve beş farklı konsantrasyondan sadece en yüksek doz olan $250 \mu \mathrm{g} / \mathrm{plak}$ uygulamasinda her iki test suşunda da S9 varlığında ve yokluğunda mutajenik aktiviteye rastlanmıştır. Diğer konsantrasyonlarda ise koloni sayılarında değişiklikler olmasına rağmen kontrol grubunun iki katını aşan değerlere ulaşmadığ için herhangi bir mutajenik aktivite görülmemiştir. Günümüze kadar yapılan çalışmalarda pek çok farklı sonuç elde edilmiştir. Bunun sebebinin aynı gruba dahil pestisitler olmasına rağmen pestisitlerin yan zincirlerinde yer alan farklı grup ve yapılardan kaynaklandığı söylenebilir.

Ayrıca test bileşenlerinin bakteri hücre duvarından geçmiş olması direkt olarak DNA ile etkileşeceğini göstermemektedir. Bileşiğin sitoplazmik konsantrasyonu yüksek olsa dahi, sitoplazmik alanda bakteriyel genomda bulunan özgül bağlanma bölgeleriyle kompleks oluşturmayabilir. $\mathrm{Bu}$ sebeple, kimyasal maddenin DNA ile etkileşimi görülmeyebilir (Kayaalp, 1995). Buna bağlı olarak da, çalışılan

\section{KAYNAKLAR}

Aky11 D, Erdoğmuş SF, Eren Y, Özkara A, Korcan E, 2013. Potential antimicrobial and antimutagenic activities of Astragalus flavescens. Fresenius Environmental Bulletin, 22(7): 18681873.

Alzuet PR, Gaspes E, Ronco AE, 1996. Mutagenicity of Enviromental Samples from an Industrialized Area of the Rio de la Plata Estuary using the Salmonella/Microsomal Assay. Environmental Toxicology and Water Quality, 11: 231-236.

Coral MN, Uçman S, Yıldız H, Öztaş H, Dalkılıç S, 2009. Potential neoplastic effects of parathion-methyl on rat liver. Journal of Environmental Sciences, 21(5): 696-699.

Çolak İ, 2009. Sentetik piretroidlerde enantiomerik analiz yöntemlerinin geliştirilmesi. Marmara Üniversitesi Fen Bilimleri Enstitüsü, Doktora Tezi, İstanbul. kimyasalların mutajenik olması ya da herhangi bir mutajenik aktivite göstermemesi bahsedilen etkenlere bağlı olarak farklılık gösterebilmektedir. Bu çalışma ve yapılan diğer çalışmalar gösteriyor ki, uygulanan maddelerin kimyasal yapısı ve ortaya çıkan biyolojik aktivite arasında önemli bir ilişki vardır. Kimyasal maddelerin yapısında bulunan halkaların; grup sayılarının, niteliğinin, bağlanma konumlarının, pozisyonlarının bu yapı-etki ilişkisindeki yeri oldukça önemlidir (Öztaş, 2005). Aynı zamanda pestisitlerin toksik etkilerini göstermeleri aşamasında maddelerin alınış şekli, temasın süresi, yağdaki çözünürlüğü ve maddenin vücutta hidroliz olma özelliği, toksinin doğrudan etki etmesi veya önce metabolize olup aktif hale geçtikten sonra etki etmesi gibi bazı sebepler önemli rol oynamaktadır (Namba et al., 1972; Scharf et al., 1992; Vural, 1996).

\section{SONUÇ}

Yapılan bu çalışma sonucunda piretroid ester grubuna giren bir insektisit olan Dentis pestisitinin mutajenitesi TA98 ve TA100 suşları kullanılarak Ames testi ile denenmiş ve uygulanılan dozlardan sadece $250 \mu \mathrm{g} / \mathrm{plak}$ dozunda her iki test suşunda da S9 varlığı ve yokluğunda mutajenik aktivitesinin olduğu saptanmıştır. Bu bağlamda pestisit kullanımı sırasında doz aşımının büyük problemler doğurabileceği göz önünde bulundurulmalı ve pestisitin yüksek dozlarının kullanımının işçi ve halk sağlı̆̆ açısından zararlı etkiler meydana getirebileceği düşünülerek bilinçli bir tüketim sağlanmalıdır.

Dean BJ, Brooks TM, Hodson-Walker G, Hutson DH, 1985. Genetic toxicology testing of 41 industrial chemicals. Mutation Research, 153: 57-77.

Eren Y, Erdoğmuş SF, Akyıl D, Özkara A, 2016. Mutagenic and cytotoxic activities of benfuracarb insecticide. Cytotechnology, 68(4): 637-43.

Fuse I, Higuchi W, Uesugi Y, Aizawz Y, 2001. Pathogenic analysis of three cases with a bleeding disorder characterized by defective platelet aggregation induced by $\mathrm{Ca}^{+2}$ ionophores. British Journal of Haematology, 112(3): 603-608.

Healy CE, Kier LD, Broeckaert F, Martens MA, 2003. A review of the genotoxicity of triallate. International Journal of Toxicology, 22(3): 233-251.

Herrera A, Laborda E, 1988. Mutagenic activity in synthetic pyrethroids in Salmonella typhimurium. Oxford Journals Life Sciences \& Medicine Mutagenesis, 3: 509-514. 
Kayaalp O, 1995. Tıbbi Farmakoloji, Hacettepe Taş Yayınları, Ankara.

Kim SJ, Rim KT, Kim HY, Yang JS, 2010. Mutagenicity of octane and tetrasodium pyrophosphate in bacterial reverse mutation (Ames) test. The Journal of Toxicological Sciences, 35(4): 555-562.

Maron DM, Ames BN, 1983. Revised methods for the mutagenicity test. Mutation Research, 113: 173-215.

Mortelmans K, Zeiger E, 2000. The Ames Salmonella/microsome mutagenicity assay. Mutation Research, 445: 29-60.

Namba T, Nolte C, Jackrel J, Grob D, 1972. Poisoning due to organophosphate insecticides, acute and chronic manifestations. The American Journal of Medicine, 50: 475492.

Oğuz S, 2011. Mutajenik-Karsinojenik Etkinin Ames Testi İle Araștırılması. Marmara Üniversitesi Sağlık Bilimleri Enstitüsü, Yüksek Lisans Tezi, 81s, İstanbul.

Öztaş E, 2005. Bazı 9-sübstitüe fenantren türevlerinin mutajenik aktivitelerinin Ames/Salmonella/Mikrozom testi ile araştırılması. Anadolu Üniversitesi Fen Bilimleri Enstitüsü, Yüksek Lisans Tezi, Eskișehir

Piner P, 2009. Lamda-cyhalohrinin Oreochromis niloticus'da karaciğerde piperonil bütoksit modülatörlüğünde oksidatif stres potansiyelinin belirlenmesi, stres proteinleri ve apoptozis üzerine etkileri. Cukurova Üniversitesi Fen Bilimleri Enstitüsü, Doktara Tezi, Adana.

Pluijmen M, Drevon C, Montesano R, Malaveille C, Hautefeuille A, Bartsch H, 1984. Lack of mutagenicity of synthetic pyrethroids in Salmonella typhimurium strains and in V79
Chinese hamster cells. Mutation Research, 1: 7-17.

Romero A, Ramos E, Castellano V, Martínez MA, Ares I, Martínez M, Martínez-Larrañaga MR, Anadón A, 2012. Cytotoxicity induced by deltamethrin and its metabolites in SH-SY5Y cells can be differentially prevented by selected antioxidants. Toxicology in Vitro, 26: 823-830.

Scharf J, WiesiolIek R, Bachmann K, 1992. Pesticides in atmosphere. Fresenius Journal of Analytical Chemistry, 342: 813-816.

Soderlund DM, Clark JM, Sheets LP, Mullin LS, Piccirillo VJ, Sargent D, Stevens J. T, Weiner ML, 2002. Mechanisms of pyrethroid neurotoxicity: implications for cumulative risk assessment. Toxicology, 171: 3-59.

Song Y, Kai J, Song X, Zhang W, Li L, 2015. Long-term toxic effects of deltamethrin and fenvalerante in soil. Journal of Hazardous Materials, 289: 158-164.

Verma R, Awasthi KK, Rajawat NK, Soni I, John PJ, 2016. Curcumin modulates oxidative stress and genotoxicity induced by a type II fluorinated pyrethroid, beta-cyfluthrin, Food and Chemical Toxicology, 97: 168-176.

Villarini M, Moretti M, Pasquini R, Scassellati-Sforzolini G, Fatigoni C, Marcarelli M, Monarca S, Rodri'guez AV, 1998. In vitro genotoxic effects of the insecticide deltamethrin in human peripheral blood leukocytes: DNA damage (comet assay) in relation to the induction of sister-chromatid exchanges and micronuclei.Toxicology, 130: 129-139.

Vural N, 1996. Toksikoloji. Ankara Üniversitesi Basımevi, 344363, Ankara 